\title{
FAKTOR-FAKTOR YANG MEMPENGARUHI KESEDIAAN BERBELANJA DI PASAR TRADISIONAL WILAYAH KABUPATEN SUKOHARJO
}

\author{
Bambang Nurcahya Ningrum ${ }^{1}$, Purwanto ${ }^{2}$ \\ ${ }^{1}$ Universitas Veteran Bangun Nusantara Sukoharjo \\ bambangnurcahyaningrum@gmail.com \\ ${ }^{2}$ Universitas Veteran Bangun Nusantara Sukoharjo \\ Anto.c412@gmail.com
}

\begin{abstract}
Many traditional markets in the Sukoharjo regency are not used by tenants to sell, because the visitors who want to shop are quiet. This study is to see whether risk factors, social beliefs, perceived benefits, perceived ease of use, perception of reputation, and trust, influence the willingness to shop in traditional markets. Population and research sample are people in Sukoharjo Regency. Data analysis in the study was carried out using AMOS (Analysis of Moment Structures). Research respondents were 150 respondents. This research involves students in data collection and in other implementation processes. Based on the results of the study showed that the benefits, perceived ease of use, perception of perception, risk perception, perception of social trust, perception of reputation, did not have a positive effect on the willingness to shop in traditional markets. Consumer attitudes positively influence the willingness to shop in traditional markets. Perceptions of benefits have a positive effect on perceptions of social trust. Perceptions of social trust have a positive effect on perceptions of reputation. Perception of benefits does not have a positive effect on perceptions of reputation. Perception of reputation does not have a positive effect on perceptions of trust. Perceptions of social trust do not have a positive effect on perceptions of trust. Perceptions of trust have a positive effect on consumer attitudes in traditional markets.
\end{abstract}

Keywords: Market, Shopping, Community.

(C) 2018 JBTI. All rights reserved

Article history : received 15 Sep 2018; revised 24 Sep 2018; accepted 20 Okt 2018

\section{PENDAHULUAN}

Pengertian pasar secara luas adalah adanya transaksi antara penjual dan pembeli, terdapat transaksi permintaan dan penawaran antara dua belah pihak, mengenai apa yang dibutuhkan oleh pembeli maupun yang ditawarkan oleh penjual. Pengertian pasar yang lebih sempit adalah tempat bertemunya antara penjual dan pembeli, dalam rangka melakukan jual beli barang dan jasa.

Penduduk Indonesia saat ini berjumlah sekitar 260 juta, ditambah para turis yang berwisata ke Indonesia, menyebabkan banyak pasar baru yang terbentuk di Indonesia. Pasar di Indonesia pada umumnya di bagi dalam dua jenis, yaitu pasar modern dan pasar tradisional. Masyarakat sering ke pasar modern atau pasar tradisional untuk memenuhi kebutuhan sehari-hari maupun mencari barang-barang untuk memenuhi keinginan.

Pasar tradisional di Kabupaten Sukoharjo banyak yang tidak digunakan oleh penyewanya untuk berjualan. Hal tersebut dikarenakan semakin sepinya pengunjung yang berbelanja di pasar tradisional. Menurut data dari Dinas Perdagangan Koperasi dan Usaha Kecil dan Menengah 
(Disdagkop dan UKM) Sukoharjo, terdapat 730 kios dan los yang tidak digunakan oleh pemiliknya untuk berjualan.

Berdasarkan uraian di atas, terlihat bahwa terdapat permasalahan semakin sepinya pasar tradisional di daerah Kabupaten Sukoharjo. Pada penelitian ini penulis akan meneliti faktorfaktor yang mempengaruhi keputusan masyarakat dalam melakukan transaksi di pasar tradisional khususnya di Kabupaten Sukoharjo. Urgensi atau keutamaan penelitian ini adalah untuk mengetahui penyebab semakin ditinggalkannya pasar tradisional oleh masyarakat, khususnya di Kabupaten Sukoharjo.

Berdasarkan uraian di atas, judul penelitian yang digunakan penulis adalah "FaktorFaktor Yang Mempengaruhi Kesediaan Berbelanja di Pasar Tradisional Kabupaten Sukoharjo “.

\section{KAJIAN TEORI DAN PENGEMBANGAN HIPOTESIS}

\section{a. Persepsi manfaat berpengaruh positif terhadap persepsi kepercayaan sosial.}

Manfaat yang didapatkan dari suatu transaksi yang dilakukan, akan menimbulkan kepercayaan dari orang-orang yang telah melakukan transaksi serupa. Dengan demikian, hipotesis yang dirumuskan adalah:

H1: Persepsi manfaat berpengaruh positif terhadap persepsi kepercayaan sosial.

\section{b. Persepsi kepercayaan sosial berpengaruh positif terhadap persepsi reputasi.}

Kepercayaan sosial yang dirasakan oleh mereka yang melakukan transaksi di pasar tradisional, mereka akan menganggap bahwa tempat atau pasar yang mereka gunakan untuk melakukan transksi jual beli suatu barang dapat diyakini/dipercaya/diandalkan atau tidak. Maka hipotesis dirumuskan sebagai berikut:

H2: Persepsi kepercayaan sosial berpengaruh positif terhadap persepsi reputasi.

\section{c. Persepsi manfaat berpengaruh positif terhadap persepsi reputasi.}

Manfaat yang didapatkan dari hasil transaksi jual beli barang dengan nilai atau hasil yang didapatkan itu bagus atau buruk. Hal ini akan berdampak pada hasil akhir yakni reputasi tempat yang digunakan untuk transaksi jual beli tersebut, dalam hal ini pasar tradisional. Oleh karena itu penulis membuat hipotesis sebagai berikut:

H3: Persepsi manfaat berpengaruh positif terhadap persepsi reputasi.

\section{d. Persepsi reputasi berpengaruh positif terhadap persepsi kepercayaan.}

Reputasi pasar sangat berpengaruh pada kepercayaan yang dirasakan oleh pembeli. Apabila pasar tersebut diyakini memiliki reputasi yang baik, maka kepercayaan yang di rasakan juga akan tinggi. Apabila pasar tersebut memiliki riwayat yang buruk atau reputasi buruk, maka kepercayaan yang dimiliki juga akan lemah/rendah. Berdasaarkan uraian di atas penulis membuat hipotesis sebagai berikut:

H4: Persepsi reputasi berpengaruh positif terhadap persepsi kepercayaan.

\section{e. Persepsi kepercayaan sosial berpengaruh positif terhadap persepsi kepercayaan.}

Kepercayaan sosial yang dirasakan oleh masyarakat terhadap pasar tradisional akan mempengaruhi kepercayaaan seseorang terhadap pasar tradisional. Dengan demikian penulis merumuskan hipotesis sebagai berikut:

H5: Persepsi kepercayaan sosial berpengaruh positif terhadap persepsi kepercayaan. 


\section{f. Persepsi kepercayaan berpengaruh positif terhadap sikap konsumen pada pasar tradisional.}

Apabila konsumen percaya dengan pasar yang akan mereka gunakan sebagai tempat jual beli tersebut, maka mereka akan melakukan pembelian ulang di pasar tersebut, karena mereka merasa puas dengan transaksi yang sudah dilakukan. Berbeda dengan apabila mereka hanya memiliki tingkat kepercayaan yang rendah, maka bisa saja konsumen tidak melakukan pembelian ulang di masa yang akan datang.

H6: Persepsi kepercayaan berpengaruh positif terhadap sikap konsumen pada pasar tradisional.

\section{g. Persepsi manfaat berpengaruh positif terhadap kesediaan berbelanja.}

Konsep manfaat yang dirasakan, seperti yang didefinisikan dalam model penerimaan teknologi (TAM) oleh Davis (1989); bahwa persepsi manfaat berdampak positif pada perilaku (Palupi \& Tjahjono, 2008), sama dengan teori alasan tindakan (Ajzen dan Fishbein, 1980) dan teori perilaku terencana (Ajzen, 1991), di mana sikap mengarah pada perilaku menurut Baile (2005) menjadi persepsi manfaat. Pemanfaatan merupakan turunan kata dari kata 'Manfaat', yakni suatu penghadapan yang semata-mata menunjukan kegiatan menerima. Penghadapan tersebut pada umumnya mengarah pada perolehan atau pemakaian hal-hal yang berguna baik di pergunakan secara langsung maupun tidak langsung agar dapat bermanfaat.

Sedangkan menurut Prof. Dr. J.S. Badudu (2008) dalam Kamus Umum Bahasa Indonesia, mengatakan bahwa : "Pemanfaatan adalah hal, cara, hasil kerja dalam memanfaatkan sesuatu yang berguna". Definisi lain dari manfaat dikeluarkan oleh Dennis Mc Quail dan Sven Windahl (2007), yakni: "Manfaat merupakan harapan sama artinya dengan explore (penghadapan semata-mata menunjukan suatu kegiatan menerima)". Model ini menampilkan konsep persepsi manfaat sebagai keunggulan, bahwa seorang individu percaya dia bisa menang atau mendapat keuntungan dalam aspek tertentu, jika berbelanja di pasar tradisional.

Berdasarkan teori dan uraian di atas dapat dirumuskan hipotesis berikut ini:

H7: Persepsi manfaat (PM) berpengaruh positif terhadap kesediaan berbelanja di pasar tradisional $(\mathrm{KB})$.

\section{h. Persepsi kemudahan penggunaan berpengaruh positif terhadap kesediaan berbelanja.}

Menurut Davis dalam Kusumawati (2003), persepsi kemudahan adalah tingkat keyakinan seseorang, yaitu dengan menggunakan sistem tertentu akan bebas dari usaha. Ketika konsumen berbelanja di pasar tradisional merasa mudah, maka konsumen akan cenderung pergi ke pasar tradisional untuk berbelanja kebutuhan-kebutuhan atau memenuhi keinginan mereka mereka.

Berdasarkan teori dan uraian di atas dapat dirumuskan hipotesis berikut:

H8: Persepsi kemudahan penggunaan (PKP) berpengaruh positif terhadap kesediaan berbelanja di pasar trandisional (KB).

\section{i. H9: Persepsi kepercayaan berpengaruh positif terhadap kesediaan berbelanja.}

Menurut Lee (2009) Kepercayaan adalah yakin terhadap orang lain dengan harapan orang lain tidak akan berperilaku oportunis. Ini merupakan keyakinan bahwa pihak lain akan berperilaku sesuai etika sosial dan terdapat keyakinan bahwa pihak yang dipercaya akan memenuhi komitmen. Menurut Ainur Rofiq (2007: 30) Kepercayaan merupakan sebuah pondasi dari bisnis karena transaksi bisnis antara dua pihak atau lebih akan terjadi apabila masing-masing saling mempercayai. 
Berdasarkan argumen di atas, penulis membuat hipotesis berikut:

H9: Kepercayaan (PK) berpengaruh positif terhadap kesediaan untuk berbelanja di pasar tradisional (KM).

\section{j. Persepsi resiko berpengaruh positif terhadap kesediaan berbelanja.}

Menurut A. Abas Salim (2007), Resiko merupakan ketidaktentuan "uncertainty" yang mungkin melahirkan peristiwa kerugian "loss". Nilai ekonomi didefinisikan sebagai pengukuran jumlah maksimum seseorang untuk mau mengorbankan barang dan jasanya demi memperoleh barang dan jasa lainnya (Harahap dan Hartono, 2007). Secara formal, konsep ini disebut kesediaan membayar (willingness to pay) seseorang terhadap barang dan jasa yang dihasilkan.

Menurut Dowling dan stealin (2001), risiko akan meningkat dari sejak informasi awal sampai dengan keputusan pembelian produk, jadi risiko terkait dengan kesediaan untuk membeli atau melakukan transaksi.

Berdasarkan teori dan uraian di atas, dapat dirumuskan hipotesis sebagai berikut:

H10: Persepsi resiko (R) mempunyai hubungan positif terhadap kesediaan berbelanja di pasar tradisional $(\mathrm{KB})$.

\section{k. Sikap konsumen terhadap pasar tradisional berpengaruh positif terhadap kesediaan} berbelanja di pasar tradisional.

Sikap (attitudes) konsumen adalah faktor yang berpengaruh dalam keputusan konsumen karena konsep sikap yang berkaitan dengan konsep kepercayaan (belief) dan perilaku (behavior). Sikap konsumen diharapkan akan mempengaruhi perilaku konsumen untuk bersedia berbelanja di pasar tradisional. Berdasarkan uraian tersebut, penulis merumuskan hipotesis sebagai berikut:

H11: Sikap konsumen terhadap pasar tradisional berpengaruh positif terhadap kesediaan berbelanja di pasar tradisional.

\section{Persepsi kepercayaan sosial berpengaruh positif terhadap kesediaan berbelanja.}

Kepercayaan sosial adalah harapan yang tumbuh di masyarakat, yang ditunjukkan oleh perilaku jujur, tertib, dan kerja sama atas dasar norma-norma yang dianut bersama-sama oleh anggota masyarakat.

Ada tiga elemen dasar dari kepercayaan sosial, yaitu:

a) Adanya kepercayaan (saling percaya).

b) Sistem nilai/norma-norma.

c) Hubungan kerjasama. (Https://iimazizah.wordpress.com/2013/01/06/kepercayaan-sosial/)

Menurut Mutz (2005), kebutuhan akan kontrak hukum, pengawasan, dan litigasi dalam bisnis, telah digantikan oleh kepercayaan, yang jauh lebih murah dan lebih efisien dalam melakukan bisnis. Pada saat ini, kepercayaan umum dari orang lain menjadi penting. Jika tingkat kepercayaan pada orang lain tinggi, maka akan menciptakan potensi pasar baru untuk barang dan jasa. Merupakan peluang untuk pertumbuhan ekonomi melalui perkembangan pasar tradisional.

Pasar tradisional menurut Kotler (2009) adalah suatu tempat fisik, di mana pembeli dan penjual berkumpul untuk menukarkan barang atau jasa. Pasar menjadi sebuah tempat di mana transaksi jual beli terjadi. 
Pasar tradisional merupakan pasar di mana pelaksanaannya bersifat tradisional, pembeli dan penjual bertemu secara langsung. Ciri-ciri pasar tradisional antara lain:

a) Proses jual-beli melalui tawar-menawar.

b) Barang yang disediakan umumnya barang keperluan dapur dan rumah tangga, misalkan: sayur mayur, lauk pauk dan lain-lain.

c) Harga relatif lebih murah.

d) Tempat atau area pasar tradisional biasanya terbuka dan tidak ber AC (air conditioning).

e) Biasanya terlihat becek, kotor dan tidak beraturan.

Kepercayaan dari orang lain atau masyarakat terhadap belanja di pasar tradisional, akan dapat menyebabkan niat untuk berbelanja di pasar tradisional untuk memenuhi kebutuhan atau keinginan mereka. Kebutuhan adalah fungsi dasar dari manusia yang haru dipenuhi untuk kelangsungan hidupnya, seperti: pangan (makanan), sandang (pakaian), dan papan (rumah). Keinginan merupakan sesuatu yang dibutuhkan oleh seseorang, tetapi apabila tidak terpenuhi, tidak akan mempengaruhi kelangsungan hidup seseorang, seperti: makanan yang enak, barang mewah, mobil baru, jalan-jalan ke luar negeri. Berdasarkan argumen tersebut di atas, maka penulis membuat hipotesis berikut:

H12: Persepsi kepercayaan sosial (KS) berpengaruh positif terhadap kesediaan belanja di pasar tradisional $(\mathrm{KB})$.

\section{m. Persepsi reputasi berpengaruh positif terhadap kesediaan berbelanja.}

Reputasi didefinisikan sebagai kualitas keseluruhan atau karakter yang dapat dilihat atau dinilai oleh masyarakat umum (Malaga, 2001). Penelitian Dharma (2006) menemukan bahwa tampilan muka situs e-commerce yang dianggap sebagai performa yang baik, akan menyebabkan kepercayaan. Kesaksian konsumen (testimoni) tentang pengalaman bertransaksi di toko online, dilakukan situs belanja online untuk menganggap diri mereka memiliki reputasi yang baik. Pasar tradisional memiliki reputasi yang baik, akan dipercaya oleh masyarakat apabila pedagang di pasar tradisional tersebut memberikan informasi yang benar, memberikan informasi yang dibutuhkan konsumen, dan melindungi konsumen. Reputasi pasar tradisional akan dapat mempengaruhi niat untuk berbelanja di pasar tradisional.

Berdasarkan alasan di atas, penulis membuat hipotesis sebagai berikut:

H13: Persepsi reputasi (PR) berpengaruh positif terhadap kesediaan berbelanja di pasar tradisional $(\mathrm{KB})$.

\section{TINJAUAN PUSTAKA}

Hasil dari penelitian yang dilakukan oleh Mardhianestry (2011), menunjukkan bahwa kepercayaan sosial, reputasi, persepsi manfaat, persepsi kemudahan berpengaruh positif terhadap kepercayaan. Persepsi resiko tidak berpengaruh terhadap kepercayaan. Kepercayaan tidak berpengaruh terhadap kesediaan untuk berbelanja secara online. Pada penelitian ini variable dependennya bukan berbelanja secara online, tetapi variable dependennya adalah kesediaan berbelanja di pasar tradisional. 


\section{1) Model Penelitian}

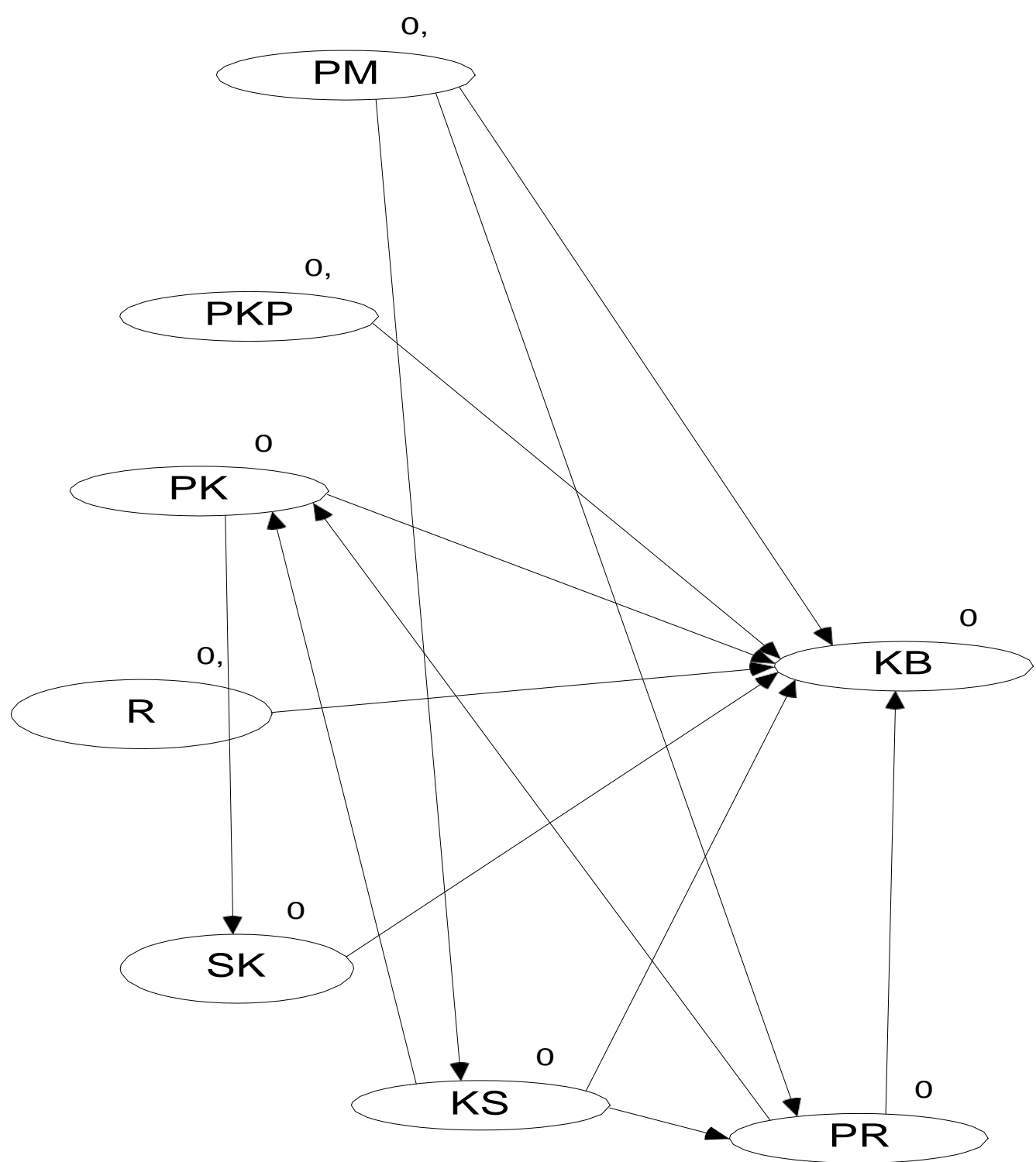

Gambar 1. Model Penelitian

\section{Keterangan:}

PM = Persepsi Manfaat

PKP = Persepsi Kemudahan Penggunaan

PK = Persepsi Kepercayaan

$\mathbf{R} \quad=$ Resiko

SK = Sikap Konsumen Terhadap Pasar Tradisional

KS = Kepercayaan Sosial

PR = Persepsi Reputasi

KB = Kesediaan Berbelanja di Pasar Tradisional 


\section{METODE PENELITIAN}

\section{a. Populasi dan Sampel Penelitian.}

Populasi yang digunakan dalam penelitian ini adalah masyarakat atau warga yang ada kemungkinan berbelanja untuk memenuhi kebutuhan atau keinginannya di wilayah Kabupaten Sukoharjo.

Karena terdapat keterbatasan dalam melakukan penelitian, maka ruang lingkup populasi dipersempit berdasarkan sampel pada warga yang pernah maupun yang berniat berbelanja di pasar tradisional di wilayah Kabupaten Sukoharjo.

Teknik penentuan sampel dengan menggunakan teknik convenience sampling. Metode convenience sampling adalah metode pemilihan sampel dari elemen populasi yang datanya mudah diperoleh peneliti dengan mendatangi masyarakat yang berpotensi berbelanja di pasar tradisional baik sebagai pengguna akhir maupun yang sebagai pedagang atau berbelanja untuk dijual lagi. Metode ini termasuk dalam kategori non-probability sampling. (Tjahjono, 2015)

\section{b. Sumber Data dan Teknik Pengambilan Sampel.}

Data yang digunakan dalam penelitian adalah data langsung yang diperoleh dari sumber data pertama yang ada di lokasi penelitian atau obyek penelitian. Teknik pengambilan sampel dengan menggunakan teknik aksidental didasarkan pada kemudahan/convenience.

\section{c. Teknik Pengumpulan Data.}

Pengumpulan data dalam penelitian ini menggunakan metode angket atau kuesioner. Sebelum digunakan peneliti menyeleksi kuesioner untuk mendapatkan kuesioner yang memiliki syarat-syarat seperti identitas, item pertanyaan, usia, pendidikan, umur, jenis kelamin sudah terisi dengan lengkap.

\section{d. Variabel Sampel.}

Variabel yang akan diteliti dalam penelitian ini dapat diklasifikasikan sebagai berikut:

1) Variabel dependen yaitu kesediaan berbelanja di pasar tradisional, kepercayaan (trust), reputasi (reputation), kepercayaan sosial (social trust).

2) Variabel independen terdiri atas, risiko (risk), persepsi kemudahan penggunaan (ease of use) dan persepsi manfaat (perceived of risk).

\section{e. Teknik Analisis Data.}

Analisis data dalam penelitian ini menggunakan AMOS (Analisis of Moment Structures), yang digunakan sebagai pendekatan umum analisis data dalam Model Persamaan Struktural (Structural Equation Model) atau yang dikenal dengan SEM.

\section{f. Teknik Pengujian Data.}

1) Analisis Deskriptif

Analisis deskriptif berisi pembahasan secara deskriptif mengenai tanggapan yang diberikan oleh responden terhadap kuesioner. Statistik deskriptif merupakan statistik yang digunakan untuk menganalisis data, dengan cara mendeskripsikan atau menggambarkan data yang telah terkumpul, sebagaimana adanya tanpa bermaksud membuat kesimpulan yang berlaku untuk umum atau generalisasi.

2) Pengujian Instrumen

a. Uji Validitas

Uji validitas merupakan uji untuk mengukur sah atau valid tidaknya suatu kuesioner. Suatu kuesioner dikatakan valid, apabila pertanyaan dalam kuesioner 
tersebut mampu untuk mengungkapkan sesuatu yang akan diukur oleh kuesioner tersebut (Ghozali, 2013). Uji validitas pada penelitian ini menggunakan confirmatory factor analysis (CFA). Suatu item pernyataan akan dikatakan valid, jika memiliki loading factor $\geq 0.50$ (Ferdinand, 2006).

b. Uji Reliabilitas

Reliabilitas adalah alat untuk mengukur suatu kuesioner yang merupakan indikator dari variabel atau konstruk. Suatu kuesioner akan dianggap reliabel atau handal, jika jawaban seseorang terhadap suatu pernyataan adalah konsisten atau stabil dari waktu ke waktu (Ghozali, 2013). Nilai reliabilitas yang diterima adalah $\geq 0.60$ (Sekaran \& Bougie, 2017).

c. Uji Hipotesis

Untuk menguji hipotesis dalam penelitian ini menggunakan metode Structural Equation Modeling (SEM). Hal-hal yang perlu diperhatikan dalam melakukan pengujian dengan pendekatan SEM yaitu asumsi model, analisis kesesuaian model dan analisis koefisien jalur. Penjelasan dari masing-masing analisis adalah sebagai berikut:

1) Asumsi Model

a. Normalitas data

Asumsi yang paling fundamental dalam analisis multivariate adalah normalitas, yang merupakan bentuk suatu distribusi data pada suatu variabel metrik tunggal dalam menghasilkan distribusi normal (Hair et al., 2010). Apabila asumsi normalitas tidak dipenuhi dan penyimpangan normalitas tersebut besar, maka akan mengakibatkan hasil uji statistik yang bias. Normalitas dibagi menjadi dua, yaitu: (1) Univariate normality, (2)Multivariate normality

Untuk menguji asumsi normalitas, maka dapat digunakan nilai statistik $\mathrm{z}$ untuk skewness dan kurtosisnya. Curran et al. (dalam Ghozali \& Fuad, 2005) membagi distribusi data menjadi tiga bagian:

(1) Normal, apabila nilai z statistik (Critical Ratio atau C.R.) skewness $<2$ dan nilai C.R. kurtosis $<7$.

(2) Moderately non-normal, apabila nilai C.R. skewness berkisar antara 2 sampai 3 dan nilai C.R. kurtosis berkisar antara 7 sampai 21.

(3) Extremely non-normal, apabila nilai C.R. skewness $>3$ dan nilai C.R. kurtosis $>21$.

b. Evaluasi outlier

Outliers adalah observasi atau data yang memiliki karakteristik unik yang terlihat sangat berbeda jauh, dari observasi-observasi lainnya dan muncul dalam bentuk nilai ekstrim, baik untuk sebuah variabel tunggal atau variabel kombinasi (Hair et al., dalam Ferdinand, 2006). Uji terhadap multivariate outliers dilakukan dengan menggunakan kriteria Jarak Mahalanobis pada tingkat $\mathrm{p}<0,001$. Jarak Mahalanobis itu dievaluasi dengan menggunakan $\chi^{2}$ pada derajat bebas sebesar jumlah variabel yang digunakan dalam penelitian (Ferdinand, 2006).

c. Analisis Kesesuaian Model (Goodness-of-fit)

Indeks-indeks yang digunakan untuk menguji kelayakan model diringkas dalam tabel berikut: 
Tabel 2. Goodness-of-fit Indices

\begin{tabular}{|l|l|}
\hline Goodness-of-fit Indices & Cut-off Value \\
\hline Chi-square $\left(\chi^{2}\right)$ & Diharapkan kecil \\
\hline Degrees of freedom & Positif \\
\hline Significance Probability $(p)$ & $\geq 0,05$ \\
\hline CMIN/DF & $\leq 2,00$ \\
\hline GFI & $\geq 0,90$ \\
\hline AGFI & $\geq 0,90$ \\
\hline TLI & $\geq 0,90$ \\
\hline CFI & $\geq 0,90$ \\
\hline RMSEA & $\leq 0,08$ \\
\hline Sumb: (Ferdinand & \\
\hline
\end{tabular}

Sumber: (Ferdinand, 2006)

d. Analisis Koefisien Jalur

Analisis ini dilihat dari signifikansi besaran regression weight model.

Kriteria bahwa jalur yang dianalisis signifikan adalah apabila memiliki nilai C.R. $\geq$ nilai t tabel atau tingkat signifikansi (p) yang lebih kecil dari 5\% (Ferdinand, 2006).

\section{HASIL DAN PEMBAHASAN}

\section{a. Analisis Deskriptif}

Analisis deskriptif bertujuan untuk mengetahui karakteristik dan untuk mengetahui tanggapan responden terhadap item-item pernyataan dalam kuesioner. Responden dalam penelitian ini adalah warga yang pernah maupun yang berniat berbelanja di pasar tradisional di wilayah Kabupaten Sukoharjo. Pengambilan sampel dalam penelitian ini menggunakan metode convenience sampling, yakni pengambilan sampel dari populasi berdasarkan kemudahan (Sekaran \& Bougie, 2017). Pengambilan data dilakukan dengan metode survey, peneliti memberikan kuesioner dan mewancarai responden secara langsung.

Dalam penelitian ini peneliti bersama tim berhasil mendapatkan 162 responden. Ternyata terdapat 132 kuesioner yang lengkap dan layak untuk diolah.

Tabel 3. Hasil Data Lapangan

\begin{tabular}{|c|l|c|}
\hline No. & \multicolumn{1}{|c|}{ Keterangan } & Jumlah \\
\hline 1. & Kuesioner yang terkumpul & 162 \\
\hline 2. & Kuesioner yang tidak lengkap dan rusak & 12 \\
\hline 3. & Kuesioner yang digunakan & 150 \\
\hline
\end{tabular}

\section{b. Uji Instrumen Penelitian}

\section{1) Uji Validitas dan Reliabilitas.}

Pengujian validitas dilakukan pada delapan variabel dalam penelitian ini. Hasil uji validitas menunjukkan semua item pernyataan dalam kuesioner memiliki tingkat validitas yang baik, yaitu memiliki loading factor $\geq 0.50$. Uji reliabilitas yang dilakukan didapatkan 
hasil yaitu: persepsi manfaat sebesar 0.901 ; persepsi kemudahan penggunaan sebesar 0.828; persepsi kepercayaan sebesar 0.867; persepsi resiko sebesar 0.849; sikap konsumen terhadap pasar sebesar 0.791; kesediaan untuk berbelanja sebesar 0.791 ; persepsi kepercayaan sosial sebesar 0.601 ; persepsi reputasi sebesar 0.779 , nilai reliabilitas yang diterima adalah $\geq 0.60$.

\section{2) Full Structural Equation Model Analysis}

Analisis model persamaan struktural secara penuh (full structural equation model analysis) adalah sebagai berikut:

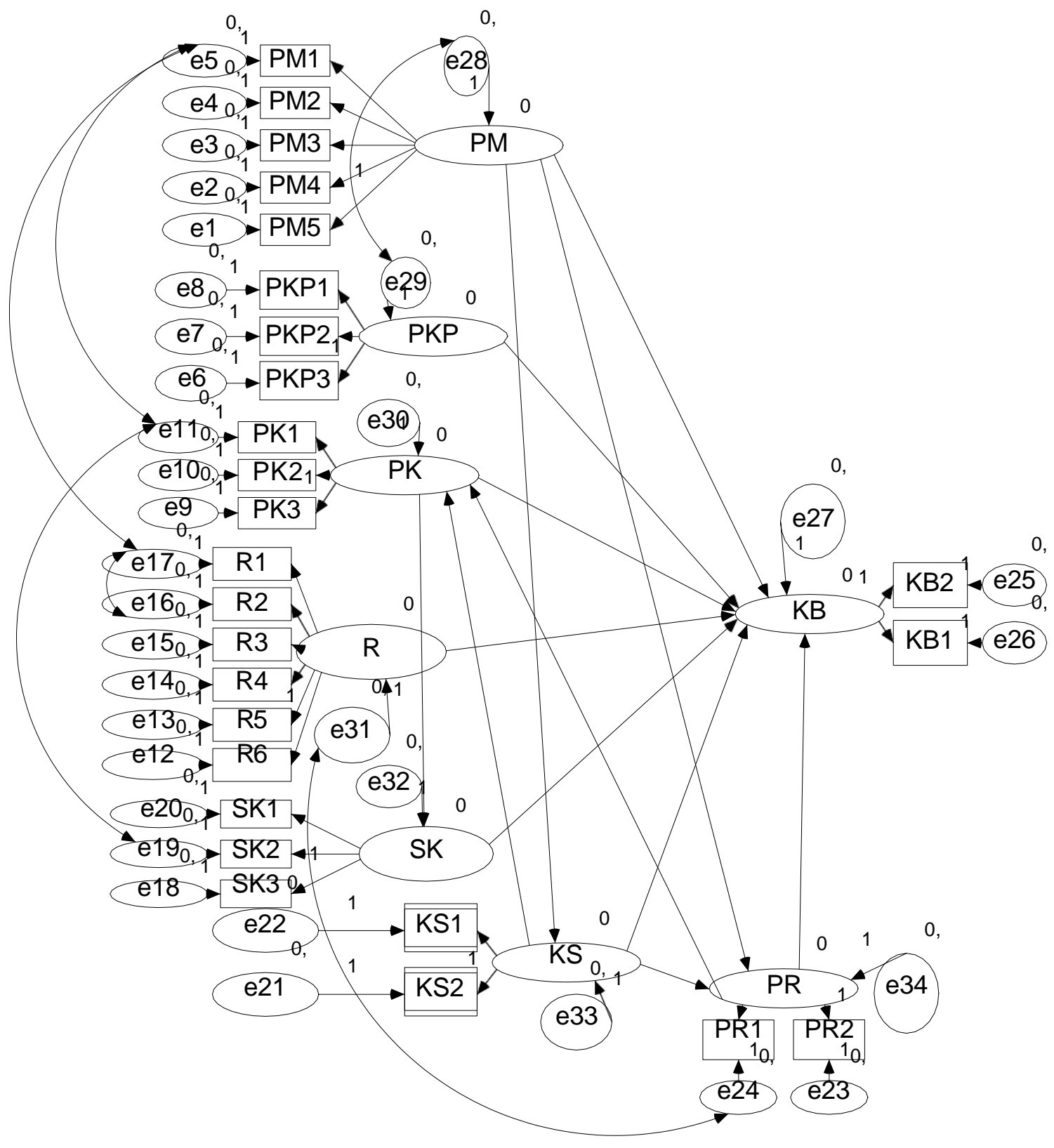

Gambar 2. Model Persamaan Struktural Secara Penuh 


\section{3) Penilaian Kriteria Goodness of Fit Index}

Analisis Kesesuaian Model (Goodness-of-Fit).

Tabel 4. Hasil Uji Goodness-of-fit Model

\begin{tabular}{|l|l|l|l|}
\hline \multicolumn{1}{|c|}{$\begin{array}{c}\text { Goodness-of-fit } \\
\text { Indices }\end{array}$} & \multicolumn{1}{c|}{ Cut-off Value } & \multicolumn{1}{c|}{ Hasil } & \multicolumn{1}{c|}{ Evaluasi Model } \\
\hline $\begin{array}{l}\text { Chi-Square }\left(\chi^{2}\right) \\
\begin{array}{l}\text { Degrees of Freedom } \\
(\text { DF })\end{array}\end{array}$ & Diharapkan kecil & 458.347 & - \\
\hline $\begin{array}{l}\text { Significance } \\
\text { Probability }(p)\end{array}$ & $\geq 0,05$ & 280 & Fit \\
\hline CMIN/DF & $\leq 2,00$ & 0,000 & Belum memenuhi \\
\hline TLI & $\geq 0,90$ & 0,903 & Fit \\
\hline CFI & $\geq 0,90$ & 0,916 & Fit \\
\hline RMSEA & $\leq 0,08$ & 0.065 & Fit \\
\hline
\end{tabular}

Sumber: Data Primer yang diolah, 2018

Berdasarkan hasil tersebut di atas, maka dapat disimpulkan bahwa secara keseluruhan model dapat diterima. Menurut Hair et al. (2010) untuk model penelitian seperti SEM menggunakan tiga sampai empat indeks yang pas untuk menyediakan bukti yang memadai untuk sebuah model. Selain menunjukkan nilai chi-square $\left(\chi^{2}\right)$ dan degress of freedom juga harus menunjukkan nilai CFI, TLI, dan RMSEA, karena beberapa indeks ini dianggap sudah cukup untuk mengevaluasi suatu model.

\section{c. Pengujian Hipotesis}

\section{Asumsi Model}

a. Evaluasi Outliers

Tidak terdapat kasus yang dikategorikan sebagai outliers, karena semua item memiliki jarak mahalanobis di bawah jarak mahalanobis kritis yaitu 54.052.

\section{b. Normalitas Data}

Evaluasi normalitas diidentifikasi baik secara univariate maupun multivariate. Secara univariate untuk nilai-nilai dalam C.r skewness, diantara -2.58 sampai 2.58 . Dengan demikian data terdistribusi normal.

\section{c. Evaluasi Multikolinieritas}

Korelasi antar variabel independen dapat dilihat pada Tabel 4.12 yang menunjukkan bahwa korelasi antar variabel independen tidak melebihi 0,80 sehingga dalam penelitian ini tidak terjadi multikolinearitas.

\section{Analisis Kesesuaian Model (Goodness-of-Fit)}

Tabel 5. Hasil Uji Goodness-of-fit Model

\begin{tabular}{|l|l|l|l|}
\hline $\begin{array}{l}\text { Goodness-of-fit } \\
\text { Indices }\end{array}$ & Cut-off Value & Hasil & Evaluasi Model \\
\hline $\begin{array}{l}\text { Chi-Square }\left(\chi^{2}\right) \\
\begin{array}{l}\text { Degrees of Freedom } \\
(\text { DF })\end{array}\end{array}$ & Diharapkan kecil & 458.347 & - \\
\hline $\begin{array}{l}\text { Significance } \\
\text { Probability }(p)\end{array}$ & $\geq 0,05$ & 280 & Fit \\
\hline CMIN/DF & $\leq 2,00$ & 0,000 & Belum memenuhi \\
\hline TLI & $\geq 0,90$ & 1,637 & Fit \\
\hline
\end{tabular}




\begin{tabular}{|l|l|l|l|}
\hline $\begin{array}{l}\text { Goodness-of-fit } \\
\text { Indices }\end{array}$ & Cut-off Value & Hasil & Evaluasi Model \\
\hline CFI & $\geq 0,90$ & 0,916 & Fit \\
\hline RMSEA & $\leq 0,08$ & 0.065 & Fit \\
\hline
\end{tabular}

Sumber: Data Primer yang diolah, 2018

Berdasarkan hasil tersebut di atas, maka dapat disimpulkan bahwa secara keseluruhan model dapat diterima. Menurut Hair et al. (2010) untuk model penelitian seperti SEM menggunakan tiga sampai empat indeks yang pas untuk menyediakan bukti yang memadai untuk sebuah model. Selain menunjukkan nilai chi-square $\left(\chi^{2}\right)$ dan degress of freedom juga harus menunjukkan nilai CFI, TLI, dan RMSEA, karena beberapa indeks ini dianggap sudah cukup untuk mengevaluasi suatu model.

\section{Analisis Koefisien Jalur}

Analisis ini dilihat dari signifikansi besaran regression weight model yang dapat dilihat pada tabel 6 berikut ini:

Tabel 6. Regression Weigts

\begin{tabular}{|c|c|c|c|c|c|c|}
\hline & & & Estimate & S.E. & C.R. & $\mathbf{P}$ \\
\hline Persepsi Kepercayaan Sosial & $<---$ & Persepsi Manfaat & .261 & .071 & 3.668 & $* * *$ \\
\hline Persepsi Reputasi & <--- & Persepsi Kepercayaan Sosial & 1.350 & .317 & 4.255 & $* * *$ \\
\hline Persepsi Reputasi & $<--$ & Persepsi Manfaat & .199 & .112 & 1.775 & .076 \\
\hline Persepsi Kepercayaan & $<--$ & Persepsi Reputasi & .277 & .441 & .627 & .530 \\
\hline Persepsi Kepercayaan & $<--$ & Persepsi Kepercayaan Sosial & .686 & .821 & .835 & .404 \\
\hline $\begin{array}{l}\text { Sikap Konsumen Terhadap } \\
\text { Pasar Tradisional }\end{array}$ & $<---$ & Persepsi Kepercayaan & .746 & .079 & 9.406 & $* * *$ \\
\hline Kesediaan Berbelanja & $<---$ & Persepsi Manfaat & .220 & .137 & 1.602 & .109 \\
\hline Kesediaan Berbelanja & $<--$ & $\begin{array}{l}\text { Persepsi Kemudahan } \\
\text { Penggunaan }\end{array}$ & .154 & .113 & 1.360 & .174 \\
\hline Kesediaan Berbelanja & <--- & Persepsi Kepercayaan & -.289 & .128 & -2.255 & .024 \\
\hline Kesediaan Berbelanja & <--- & Resiko & -.016 & .070 & -.232 & .817 \\
\hline Kesediaan Berbelanja & $<---$ & $\begin{array}{l}\text { Sikap Konsumen Terhadap } \\
\text { Pasar Tradisional }\end{array}$ & .265 & .130 & 2.036 & .042 \\
\hline Kesediaan Berbelanja & $<---$ & Persepsi Kepercayaan Sosial & 1.707 & .971 & 1.758 & .079 \\
\hline Kesediaan Berbelanja & $<---$ & Persepsi Reputasi & -.199 & .497 & -.400 & .689 \\
\hline
\end{tabular}

Sumber: Data Primer yang diolah, 2018.

Hasil pengujian ini menunjukkan bahwa dari tiga belas jalur yang dianalisis, terdapat empat jalur yang memiliki pengaruh yang signifikan, terlihat dari besarnya tingkat Critical Ratio $(\mathrm{CR})>1,96$ dan nilai Probability $(\mathrm{P})<0,05$. Dapat disimpulkan bahwa:

a. H1: Persepsi manfaat berpengaruh positif terhadap persepsi kepercayaan sosial. Disimpulkan bahwa H1 didukung. Hasil dari penelitian ini menunjukkan, bahwa persepsi manfaat yang meliputi: efektifitas berbelanja, penghematan waktu berbelanja, kemudahan layanan, suasana yang menyenangkan pada saat berbelanja di pasar tradisional dapat membuat pembeli merasa nyaman .Mereka merasa senang dan merasa mudah untuk berbelanja di pasar tradisional sehingga akan berpengaruh terhadap kepercayaan masyarakat terhadap pasar tradisional.

b. H2: Persepsi kepercayaan sosial berpengaruh positif terhadap persepsi reputasi. Disimpulkan bahwa $\mathrm{H} 2$ didukung. Hasil dari penelitian ini menunjukkan, bahwa pendapat dan pengalaman orang lain mencerminkan baik atau buruknya tentang pasar 
tradisional hal ini akan mempengaruhi tingkat reputasi pasar tradisional. Berdasarkan pendapat orang lain yang positif tentang pasar tradisional, maka orang tersebut akan berpersepsi bahwa pasar tradisional dapat dipercaya dan dapat diandalkan. Sebaliknya jika seseorang berpendapat buruk tentang pasar tradisonal maka pembeli juga akan berfikir ulang untuk membeli di pasar tradisional karena sudah mendengar pendapat orang lain yang kurang baik mengenai pasar tersebut.

c. H3: Persepsi manfaat berpengaruh positif terhadap persepsi reputasi.

Disimpulkan bahwa H3 tidak didukung. Hasil di atas berarti peningkatan efektifitas berbelanja di pasar tradisional, penghematan waktu, kemudahan layanan berbelanja di pasar tradisional tidak mempengaruhi reputasi dapat dipercaya dan keandalan pasar tradisional. Hal tersebut disebabkan karena sudah menjamurnya tempat atau model belanja yang lebih efektif, lebih hemat waktu, dan layanannya lebih lengkap sehingga persepsi manfaat tidak berpengaruh pada persepsi reputasi.

d. H4: Persepsi reputasi berpengaruh positif terhadap persepsi kepercayaan.

Disimpulkan bahwa $\mathrm{H} 4$ tidak didukung. Hal ini berarti persepsi reputasi dari pasar tradisional tidak begitu diperdulikan masyarakat hal ini bisa saja terjadi karena mereka menganggap bahwa pasar tradisional itu aman dari tindak penipuan dan pasar tradisional bisa diandalkan. Maka dengan seperti persepsi reputasi tidak berpengaruh pada persepsi kepercayaan.

e. H5: Persepsi kepercayaan sosial berpengaruh positif terhadap persepsi kepercayaan.

Disimpulkan bahwa H5 tidak didukung. Hal ini dikarenakan kepercayaan pembeli terhadap pasar tradisional sudah melekat di pemikiran masing-masing individu, bahwa pasar tradisional pasti aman dari penipuan dan memiliki sistem keamanan yang cukup untuk melindungi pembeli dari kejahatan. Dengan demikian mereka tidak memperdulikan isu-isu lain selain yang mereka yakini bahwa pasar tradisional itu aman.

f. H6: Persepsi kepercayaan berpengaruh positif terhadap sikap konsumen pada pasar tradisional.

Disimpulkan bahwa H6 didukung. Hal ini berarti bentuk keamanan dari penipuan pada saat bertransaksi di pasar tradisional akan meningkatkan rasa nyaman para pembeli sehingga mereka akan dengan mudah merekomendasikan pada teman/orang lain untuk berbelanja di pasar tradisional. Dengan demikian persepsi kepercayaan berpengaruh positif pada sikap konsumen terhadap pasar tradisional.

g. H7: Persepsi manfaat berpengaruh positif terhadap kesediaan berbelanja.

Disimpulkan bahwa $\mathrm{H} 7$ tidak didukung. Hal tersebut dikarenakan orang tidak atau belum merasakan manfaat dari pasar tradisional. Manfaat di penelitian ini meliputi: efektivitas dalam berbelanja, menghemat waktu dalam berbelanja, layanan-layanan yang tersedia di pasar tradisional kurang lengkap dan masih kurang nyaman sehingga manfaat yang mereka dapat saat berbelanja di pasar tradisional belum bisa memunculkan niat mereka untuk berbelanja di pasar tradisional di masa mendatang.

h. H8: Persepsi kemudahan penggunaan berpengaruh positif terhadap kesediaan berbelanja.

Disimpulkan bahwa H8 tidak didukung. Persepsi kemudahan penggunaan tidak berpengaruh terhadap kesediaan berbelanja di pasar tradisional, karena orang masih menganggap model belanja atau tempat belanja lain yang lebih memberi kemudahan dibandingkan dengan pasar trandisional. Walaupun di pasar tradisional telah diberikan kemudahan-kemudahan dalam berbelanja ternyata belum bisa meningkatkan kesediaan berbelanja masyarakat. Hal tersebut kemungkinan disebabkan maraknya bisnis online dan semakin banyak toko-toko modern yang lebih efektif dan efisien dalam berbelanja daripada belanja di pasar tradisional. 
i. H9: Persepsi kepercayaan berpengaruh positif terhadap kesediaan berbelanja. Disimpulkan bahwa H8 tidak didukung. Walaupun di pasar tradisional sudah diberikan jaminan keamanan dari kejahatan maupun dari penipuan, ternyata belum bisa meningkatkan kesediaan berbelanja masyarakat. Hal ini disebabkan maraknya bisnis atau perdagangan secara online yang lebih mudah untuk diakses hanya melalui smartphone tanpa harus keluar rumah untuk membeli sesuatu/ barang.

j. H10: Persepsi resiko berpengaruh positif terhadap kesediaan berbelanja. Disimpulkan bahwa H10 tidak didukung. Hasil dari penelitian ini menunjukkan, bahwa resiko tidak berpengaruh positif terhadap kesediaan atau keinginan berbelanja di pasar tradisional. Hasil tersebut menunjukkan resiko berhubungan negatif terhadap kesediaan berbelanja di pasar tradisional. Semakin tinggi persepsi resiko yang diterima oleh pembeli maka kesediaan atau keinginan orang untuk berbelanja di pasar tradisional semakin rendah, begitu pula sebaliknya apabila resiko yang ditawarkan oleh pasar tradisional itu rendah, maka kesediaan atau keinginan orang untuk berbelanja di pasar tradisional semakin tinggi.

k. H11: Sikap konsumen terhadap pasar tradisional berpengaruh positif terhadap kesediaan berbelanja di pasar tradisional.

Disimpulkan bahwa H11 didukung. Hal ini berarti sikap konsumen yang berupa kenyamanan saat bertransaksi di pasar tradisional mempengaruhi kesediaan atau keinginan berbelanja di pasar tradisional. Apabila pembeli merasa nyaman, maka mereka akan bersedia melakukan pembelian di pasar tradisional. Mereka yang tidak merasakan kenyamanan saat berbelanja, maka dimungkinkan tidak bersedia melakukan pembelian ulang di pasar tradisional.

L H12: Persepsi kepercayaan sosial berpengaruh positif terhadap kesediaan berbelanja.

Disimpulkan bahwa H12 tidak didukung. Hasil dari penelitian ini menunjukkan, bahwa pendapat orang lain mengenai pasar tradisional tidak mempengaruhi kesediaan atau keinginan untuk berbelanja di pasar tradisional. Hal tersebut dikarenakan kebanyakan orang sudah mengenal tentang pasar tradisional, sehingga pendapat orang lain tidak begitu berpengaruh terhadap kesediaan atau keinginan untuk berbelanja di pasar tradisional.

m. H13: Persepsi reputasi berpengaruh positif terhadap kesediaan berbelanja Disimpulkan bahwa H13 tidak didukung. Reputasi dan keandalan pasar tradisional belum bisa meningkatkan kesediaan atau keinginan berbelanja di pasar tradisional. Hal tesebut kemungkinan disebabkan sudah banyak terdapat swalayan atau toko modern.

\section{KESIMPULAN DAN SARAN}

\section{a. Kesimpulan}

Rangkuman hasil dari hipotesis yang didukung dan tidak didukung terdapat dalam tabel berikut:

Tabel 7. Hasil Penelitian

\begin{tabular}{|l|l|c|}
\hline \multicolumn{2}{|c|}{ Hipotesis } & Hasil \\
\hline H1 & Persepsi manfaat berpengaruh positif terhadap persepsi kepercayaan sosial. & Didukung \\
\hline H2 & Persepsi kepercayaan sosial berpengaruh positif terhadap persepsi reputasi. & Didukung \\
\hline H3 & Persepsi manfaat berpengaruh positif terhadap persepsi reputasi. & Tidak Didukung \\
\hline H4 & Persepsi reputasi berpengaruh positif terhadap persepsi kepercayaan. & Tidak Didukung \\
\hline H5 & Persepsi kepercayaan sosial berpengaruh positif terhadap persepsi kepercayaan. & Tidak Didukung \\
\hline H6 & $\begin{array}{l}\text { Persepsi kepercayaan berpengaruh positif terhadap sikap konsumen pada pasar } \\
\text { tradisional. }\end{array}$ & Didukung \\
\hline
\end{tabular}




\begin{tabular}{|l|l|c|}
\hline \multicolumn{2}{|c|}{ Hipotesis } & Hasil \\
\hline H7 & Persepsi manfaat berpengaruh positif terhadap kesediaan berbelanja. & Tidak Didukung \\
\hline H8 & $\begin{array}{l}\text { Persepsi kemudahan penggunaan berpengaruh positif terhadap kesediaan } \\
\text { berbelanja. }\end{array}$ & Tidak Didukung \\
\hline H9 & Persepsi kepercayaan berpengaruh positif terhadap kesediaan berbelanja. & Tidak Didukung \\
\hline H10 & Persepsi resiko berpengaruh positif terhadap kesediaan berbelanja. & Tidak Didukung \\
\hline H11 & $\begin{array}{l}\text { Sikap konsumen terhadap pasar tradisional berpengaruh positif terhadap kesediaan } \\
\text { berbelanja di pasar tradisional. }\end{array}$ & Didukung \\
\hline H12 & Persepsi kepercayaan sosial berpengaruh positif terhadap kesediaan berbelanja. & Tidak Didukung \\
\hline H13 & Persepsi reputasi berpengaruh positif terhadap kesediaan berbelanja. & Tidak Didukung \\
\hline
\end{tabular}

\section{b. Keterbatasan}

Metode pengumpulan data dalam penelitian ini menggunakan kuesioner, namun dalam proses penyebarannya terdapat keterbatasan sebagian responden kurang antusias menjawab pertanyaan-pertanyaan.

\section{c. Saran}

Berdasarkan hasil penelitian ini, maka penulis memberikan saran sebagai berikut:

1. Saran untuk penelitian berikutnya.

Keterbatasan penyebaran kuesioner ke responden, penulis menyarankan untuk memperpendek pertanyaan-pertanyaan dalam kuesionair, tetapi mudah dipahami. Sehingga orang yang dijadikan responden lebih antusias dan serius menjawab pertanyaan-pertanyaan dalam kuesionair.

2. Saran untuk pemerintah daerah sebagai pengambil kebijakan atas pasar tradisional. Berdasarkan hasil penelitian terlihat bahwa persepsi manfaat, kemudahan penggunaan, kepercayaan, dan reputasi pasar tradisional tidak berpengaruh positif terhadap kesediaan masyarakat berbelanja di pasar tradisional. Hal tersebut berarti walaupun persepsi manfaat masyarakat terhadap pasar tradisional meningkat tetapi belum juga meningkatkan keinginan masyarakat untuk membeli di pasar tradisional, begitu juga peningkatan kemudahan penggunaan, peningkatan kepercayaan, peningkatan kepercayaan sosial, dan peningkatan reputasi pasar tradisional di masyarakat, tetap tidak meningkatkan keinginan untuk melakukan pembelian masyarakat di pasar tradisional. Hal tersebut terlihat di lapangan, walaupun pasar tradisional sudah direnovasi, diperbaiki, ditambah fasilitasnya, pasar tradisional semakin sepi pengunjung, sehingga banyak toko atau kios yang tutup. Penulis menyarankan beberapa hal, antara lain;

a) Karena banyak konsumen yang bekerja di siang hari, maka perlu dipertimbangkan pasar tradisional bisa buka 24 jam.

b) Pasar tradisional lebih diarahkan menjadi tempat kulakan, sehingga toko-toko, swalayan-swalayan modern dan para pedagang keliling belinya di pasar tradisional untuk memenuhi persediaan dagang mereka.

\section{DAFTAR PUSTAKA}

Abbas Salim., (2007), Asuransi dan Manajemen Risiko. Jakarta: Raja Grafindo Persada.

Ainur Rofiq., (2007), Pengaruh Dimensi Kepercayaan (trust) Terhadap Partisipasi Pelanggan Ecommerce (Studi Pada Pelanggan E-Commerce di Indonesia). Tesis. FPS Universitas Brawijaya-Malang. 
Al-Maghrabi, T.\& Dennis, C., 2010, Driving online shopping: Spending \& behavioral differences among women in Saudi Arabia. International Journal of Business Science \& Applied Management.

Amer, Y., Luong, L., dan Lee, S., (2009), Optimizing Order Fulfillment In A Global Retail Supply Chain, University of south Australia, Australia.

Badudu, J.S., (2008). Kamus Peribahasa: Memahami Arti dan Kiasan Peribahasa, Pepatah \& Ungkapan, Kompas-Jakarta.

Bailey, Carol A., (2017), A Guide to Qualitative Field Research. London: Sage Publication.

Bailey, J., (2005), Student Struggle with Sleeplessnes, Insomnia. http://www.associatedcontent.com (21-04-2014)

Downling, G.R., dan Stealin, R., (2001), A Model of Perceived risk and Intended Risk-Handling Activity, Journal of Consumer Research, Vol. 21.

Ferdinand, A., (2006), Buku Structural Equation Modelling Dalam Penelitian Manajemen. Edisi 5. Semarang: Badan Penerbit Universitas Diponegoro.

Ghozali, I dan Fuad., (2005), Struktural Equation Modeling: Teori, Konsep, dan Aplikasi. Semarang: Badan Penerbit Universitas Diponegoro.

Ghozali, I., (2013), Aplikasi Analisis Multivariate dengan Program IBM SPSS 21. Edisi Ketujuh. Semarang: Badan penerbit-UNDIP.

Hair et al., (2010), Multivariate Data Analysis. Edisi ketujuh. Amerika: Pearson Custom Library.

Harahap, S.S., (2008), Analisis Krisis Atas Laporan keuangan, edisi Pertama. Raja Grafondo Persada. Jakarta.

Hartono, J., (2007), Model Kesuksesan Sistem Teknologi Informasi. Yogyakarta: Andi.

Kepala Disdagkop dan UKM Sukoharjo, Sutarmo, Jumat (3/2/2017). http://sukoharjo.sorot.co/berita-784-banyak-kios-tutup-target-retribusi-pasar-taktercapai.html, diakses tanggal 04 Mei 2017.

Kotler dan Keller, (2009). Manajemen Pemasaran. Jilid I. Edisi 13, Erlangga -Jakarta.

Kusumawati D.N., (2007), Profitability and Corporate Governance Disclousure: An Indonesian Study, Jurnal Riset Akuntansi Indonesia. Vol. 10, No. 2:131-146.

Malaga, R.A., (2007), The Value of search engine optimization: An action research project at a new E-commerce site. Journal of Electronic Commerce in Organizations, 5(3), 68-82.

Mardhianestry, (2011), Faktor-Faktor Yang Mempengaruhi Kesediaan Berbelanja Secara Online Di Daerah Yogyakarta dan Jawa Tengah. Skripsi. Fakultas Ekonomi Universitas Islam Indonesia - Yogyakarta.

McLeod, R. and Schell, G. P., (2004), Management Information systems. Ninth Edition. Pearson Education Inc., New Jersey.

McQuail, D., \& Sven, W., (2007), Communication Models: For the study of Mass Communication. New York: Longman.

Mutz, D, C., (2005), Social Trust and E-commerce: Experimental Evidence For The Effect of Social Trust on Individuals Economic Behavior, Public Opinion Quarterly; Fall 2005; 69,3; ABI/INFORM Global pg.393.

Palupi, M. \& Tjahjono, H.K. (2008). Aplikasi Technology Acceptance Model (TAM) dengan mempertimbangkan Gender pada Perilaku Penggunaan Internet. Jurnal Ekonomi dan Bisnis, 9(2): 147-153. 
Sekaran \& Bougie., (2017), Buku Metode Penelitian Untuk Bisnis. Jilid 1 Edisi 6. Jakarta: Salemba Empat.

Tjahjono, H.K. (2015). Metode Penelitian Bisnis. VSM MM UMY 